of the problems to be solved, that have made necessary the provision of adequate and intelligent facilities for plant breeding. No longer can we afford to rely $\mathrm{nn}$ a division of science into the pure and the applied, and wait for a piece of research to be completed in its appropriate pigeon-hole before further progress is attempted. Nor can we expect a science without scientists, and the training of a plant breeder presents yet another of those educational problems which most university curricula have so far failed to solve. WATKIN WILLIAMS

\section{UNIVERSITY OF OXFORD SCHOOL OF FORESTRY}

$\mathrm{O}$ $\mathrm{N}$ October 1, the University of Oxford School of Forestry celebrated its golden jubilee in the Imperial Forestry Institute, which has been its home since 1950, and in St. John's College, which has been very closely associated with it throughout the fifty years of its existence. When the Royal Indian Engineering College at Coopers Hill (near Windsor) closed in 1905, training for the Indian Forest Service which had been given there since 1888 was transferred to Oxford, temporary accommodation having been secured to serve until the building promised by St. John's was ready. The director, Dr. (afterwards Sir William) Schlich, and his assistant W. R. Fisher brought over the current class of twelve probationers and thus opened the first university forestry school in Britain (or indeed the British Empire), though Edinburgh already had a lecturer in forestry. The senior of this group, A. E. Osmaston, officiated at the planting of a jubilee oak tree at the recent celebrations. This was done in Bagley Wood, which has been continuously available to the School through the generosity of St. John's, the owner of the wood for four centuries. Mr. Osmaston is one of a famous forestry family of which seven members are serving or have served in the Forest Services of India, Britain and the Colonies ; three were present on this occasion. He was assisted by one of the present students, and a gathering of about 130 persons, nearly all former students or members of the staff, witnessed the ceremony.

The jubilee address was delivered by Sir Harold Glover, one of the first students to read forestry in Oxford, his year being headed by the late Lord Robinson, sometime chairman of the Forestry Commission. Many of that year took degrees in natural sciences, as well as the Forestry Diploma. Sir Harold joined the Indian Forest Service, Oxford having been for some years the only training centre for Indian Service probationers; between 1907 and 1932, when recruitment in the United Kingdom ceased, 213 out of the total intake of 306 had passed through the School. The last five inspectors-general in India have been Oxford graduates, including the present holder of that important post.

In 1924, the School was strengthened by the establishment of the Imperial Forestry Institute to provide a centre for higher education and research for those parts of the Empire which needed such facilities: though the Institute was in no sense a part of the School, many facilities such as the library were shared, and members of the Institute staff undertook some of the teaching. The two organizations were amalgamated in 1938 to form the University Department of Forestry. In the early years, only a diploma was awarded on the work of the two or three years the course covered, but a pass degree was granted in 1918, and finally an honours degree in 1944.

The School has provided 144 recruits to the Colonial Forest Service, and since the opening of the Institute, practically all members of that Service have attended postgraduate courses in Oxford. The proportion of the officers of the United Kingdom Forestry Commission trained at Oxford has been lower, but forty-four are serving at present, and the Commission's research staff worked at Oxford before the research station at Alice Holt was established.

A lunch was given in St. John's College, the speaker being Sir Henry Beresford-Peirse, deputy directorgeneral of the Forestry Commission. He made particular reference to the very wide range of subjects covered in a university forestry course, giving it an educational value much beyond a technical training.

The average number of students over the past three years has been fifty-eight, and the number graduating twelve. There are at present students from the United Kingdom, Canada, New Zealand, South Africa, India, Pakistan, Burma, Ceylon and several Colonies. The staff now consists of the professor, one reader, sixteen demonstrators, twenty technical assistants, twelve secretarial and librarian employees and six others, and the annual expenditure approximates $£ 50,000$.

$$
\text { H. G. Champion }
$$

\section{OBITUARIES}

\section{Prof. H. K. Mookerjee}

THE death occurred very suddenly on August 18 of Prof. H. K. Mookerjee, professor and head of the Department of Zoology of the University of Calcutta. Born in 1898, Mookerjee's undergraduate days were spent in the Presidency College, Calcutta. He won the University Gold Medal in zoology in 1924, and joined the University as assistant lecturer in 1925. As the Guruprasanna Ghose Scholar, Mookerjee went to London in 1926, and worked in the Imperial College of Science and Technology under the late Prof. E. W. MacBride. His work on the development of the vertebral column attracted considerable attention. He was Sara Marshal Scholar in the Imperial College during 1927-28, and Ghose Travelling Fellow of the University of Calcutta during 1928-29. He was awarded the D.Se. of the University of London in 1930. He rejoined the University of Calcutta on his return, and in 1933 became the University professor of zoology, which post he filled with great credit until the end of his life.

Prof. H. K. Mookerjee's important contribution in the field of embryology and evolution was based on the study of development of the axial skeleton of practically all groups of the chordates starting from Balanoglossus right up to man. He pointed out further that the centrum of all the chordates is formed in the same manner according to a basic plan; in the development of the vertebral centrum of all the chordates, from Amphioxus up to the mammals, only notochord, chord sheath, and the pericordal tube formed around the latter, take part, according to Mookerjee, but not the arch-bases or other elements claimed previously. Besides this hypothesis, Mookerjee also pointed out the many characteristic changes that take place in a non-plastic organ like the vertebral column along with change 